\title{
"The Rule of Law Mechanism" and the Hungarian and Polish Resistance: European Law Against National Identity?
}

\author{
Professor Dr. iur. Christoph J. Schewe, M.E.S. \\ Fachhochschule für Verwaltung und Dienstleistung, Kiel-Altenholz/Reinfeld \\ E-mail: schewe@fhvd-sh.de \\ Dr. Thomas Blome \\ Hochschule des Bundes für öffentliche Verwaltung, Brühl \\ E-mail: thomas.blome@hsbund.de
}

Similarly to the rest of the world, the COVID-19 pandemic has also hit the European Union (EU) severely. In order to foster the process of the economic recovery of EU Member States, the EU Member States agreed on a financial aid package combined with a regulation - the conditionality mechanism - that provided for financial sanctions in the event of a breach of the rule of law. Given that the positions of Poland and Hungary in the adoption process of this regulation caused a controversy, this article examines general questions on the rule of law, the regulation and the background to the controversy.

Keywords: rule of law, conditionality mechanism, regulation on general conditional rules for the protection of the budget of the Union, national identity, democracy.

\section{Contents}

Introduction .................................. 50

1. "The Rule of Law Mechanism" and Hungarian and Polish Concerns . . . . . . . . . . . 50

2. The Rule of Law Mechanism and the Hungarian and Polish Resistance:

European Law Against National Identity and Values? . . . . . . . . . . . . 51

2.1. A Rapprochement to 'Rechtsstaatlichkeit' and 'the Rule of Law' in the

Context of European Values ..................... 51

2.2. Safeguarding the Rule of Law Under the Treaties and Article 7 TEU . . . . . . . 56

2.3. The Conditionality Mechanism Under Regulation 2020/2092 . . . . . . . . . 57

2.3.1. The Substantive Elements of the Regulation-Breaches of the Rule of Law . . . 57

2.3.2. Legal Consequences ........................ 59

2.3.3. Procedure .......................... 59

2.3.4. The Essentials of the Regulation - Positive Elements and Shortcomings . . . . 60

3. Polish and Hungarian Concerns: EU Law v. National Identity? . . . . . . . . . 60

3.1. Polish and Hungarian Concerns . . . . . . . . . . . . . . . . . . 61

3.1.1. The Various Arguments Against the Regulation Regarding a Lack of EU Competence .......................... 61

3.1.2. Pointing the Finger at Other Member States . . . . . . . . . . . . 61

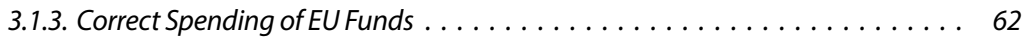


3.2. The Legal Foundation of the Polish and Hungarian Concerns . . . . . . . . . 62

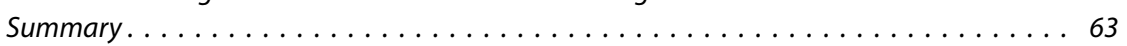

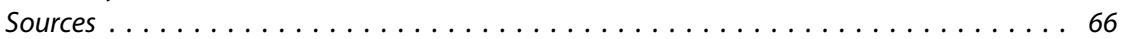

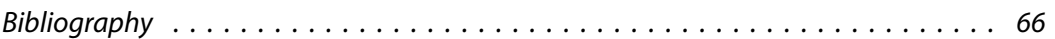

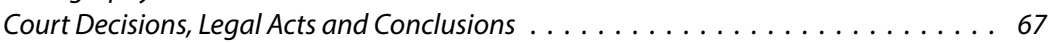

Case Law . . . . . . . . . . . . . . . . . . . . . . . 67

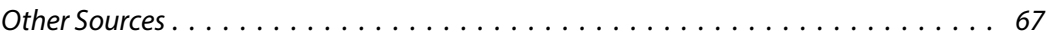

\section{Introduction}

The new conditionality mechanism aims at enhancing the rule of law in the EU Member States by sanctioning breaches of the rule of law. It establishes respective standards, which may be considered at fundamental elements of this principle and which are comparable to internationally accepted standards for the rule of law. These standards, however, are not that far reaching that they would affect the cultural and national identity of the Member States, as the Polish and Hungarian governments had claimed they would. While the new instrument may be considered as an overall positive development for securing the EU at least to certain extent against authoritarian developments in its Member States, the instrument should not be overrated. The link of breaches to the EU budget weakens the mechanism's proposed in its effect to secure the rule of law and, in the cumbersome adoption process, the procedure of the mechanism was completed with elements that prolong the process leading to potential sanctions.

\section{1. "The Rule of Law Mechanism" and Hungarian and Polish Concerns}

Why would you refuse to accept a precious, generous, and beautifully wrapped present? This is a question that could have been asked by anyone, not only Polish and Hungarian citizens, when learning about the intention of their respective governments to opt against the new financial package aiming at the recovery of the COVID-19-afflicted EU. Especially Italians and Spaniards reacted furiously, given that these states, particularly plagued by the pandemic, desperately needed these funds. Finally, the German Presidency to the EU Council found a compromise that led to the consent of all Member States to the Multiannual Financial Framework $(\mathrm{MFF})^{1}$ and the "Next Generation EU" (NGEU).

Only Poland and Hungary had initially announced the intention to block these instruments, as they were linked to the consent to the "conditionality mechanism", also named "rule of law mechanism". ${ }^{2}$ Eventually - depending on the perspective Poland and Hungary gave in ${ }^{3}$, however, only after the other 25 Member States had indicated that they might facilitate these funds without the two states and

Official Journal of the European Union, L 433I, 2020, p. 11.

2 Official Journal of the European Union, L 433I, 2020, p. 1. While most publications in press, media and political statements name the regulation "the rule of law mechanism", it might not be an entirely precise denotation. In some instances, the dialogue between the Commission and the Member State concerned from 11.03.2014 is also called rule of law mechanism (https://eur-lex.europa.eu/resource. html?uri=cellar:caa88841-aale-11e3-86f9-01aa75ed71a1.0017.01/DOC_1\&format=PDF [last viewed 01.10.2021]); in the same line, Schorkopf, F. Article 7 EUV. In: Grabitz, E., Hilf, M., Nettesheim, M. (Hrsg.). Das Recht der Europäischen Union. 69 Aufl. München, 2020, S. 60 ff. The scholarly legal debate in English language uses the term "conditionality mechanism".

3 In contrast to this interpretation, the two Member States in question declared the outcome as their victory, Hillion, C. Compromising (On) the General Conditionality Mechanism and the Rule of Law 
after considerable concessions had been made to Polish and Hungarian claims. ${ }^{4}$ Furthermore, the adoption process caused a vivid debate on its legality, given that the European Council seemed to have assumed competences ${ }^{5}$ that are not assigned to it by the Treaties. ${ }^{6}$ Despite their political agreement to the deal, on 11 March 2021, both governments brought a claim against this mechanism to the Court of Justice of the European Union (CJEU). ${ }^{7}$ Even though it is highly contested that this is in line with EU law, the European Council concluded that the regulation will not be applied until the ECJ will have decided on the matter.

Apart from this set of problems - which will not be addressed in detail in this article - the matter brings up a more general aspect: the Polish and Hungarian positions are bewildering, given that the two governments opposed something presumably positive, which in the EU and its Member States seemed to be selfevident and which formed one of the fundamental principles, - the rule of law. Hence, this raises a further set of questions: what does the rule of law mechanism imply? Do the two states have to sacrifice their core values such as family and religion to "neoliberal internationalists" under this new mechanism? Does this mechanism have a negative impact on the cultural and national identity of Member States? Does the EU have the competence to regulate this matter? Furthermore, given that other Member States do not see this danger - are they ignorant or is the mechanism specifically directed against the two Member States?

Accordingly, this contribution will explore what is to be understood under the rule of law (2.1.) and the new corresponding mechanism (2.2.), which motivates the governments of the two Member States to appear "to fight against the rule of law". In the light of this provoking image, the analysis will need to address the question, whether this mechanism really erodes (the two states') national identities and core values of Member States as the Polish and Hungarian governments had claimed (II. 3.).

\section{The Rule of Law Mechanism and the Hungarian and Polish Resistance: European Law Against National Identity and Values?}

\subsection{A Rapprochement to 'Rechtsstaatlichkeit' and 'the Rule of Law' in the Context of European Values}

The terminology regarding "the rule of law" in the various European languages is inconsistent, as the German Rechtsstaatsprinzip or the French état de droit refer to the state, and thus seem to concentrate on the state. The Latvian legal terminology

(April 6, 2021). Common Market Law Review, No. 58, 2021, pp. 267-284. Available: https://ssrn.com/ abstract $=3820897$ [last viewed 01.10.2021].

4 More in depth on the background and development Hillion, C. Compromising (On) the General Conditionality Mechanism and the Rule of Law (April 6, 2021), pp. 267-284.

5 European Council conclusions, EUCO 22/20 CO EUR 17 CONCL 8, 11 December 2020.

6 Alemanno, A., Chamon, M. To Save the Rule of Law you Must Apparently Break It. VerfBlog. 11.12.2020. Available: https://verfassungsblog.de/to-save-the-rule-of-law-you-must-apparentlybreak-it/ [last viewed 01.10.2021]. DOI: 10.17176/20201212-060201-0; Scheppele, K. L., Pech, L., Kelemen, R. D. Never Missing an Opportunity to Miss an Opportunity: The Council Legal Service Opinion on the Commission's EU budget-related rule of law mechanism. VerfBlog. 12.11.2018. Available: https://verfassungsblog.de/never-missing-an-opportunity-to-miss-an-opportunity-the-councillegal-service-opinion-on-the-commissions-eu-budget-related-rule-of-law-mechanism/ [last viewed 01.10.2021]. DOI: $10.17176 / 20181115-215538-0$.

7 The main points of the claims are accessible on the Court's website: Hungary: C-156/21; Poland: C-157/21. 
appears to be either more precise or more mediative, given that it distinguishes between tiesiska valsts and likuma vara. Notwithstanding these linguistic differences, also the efforts to define the concept of the rule of law have been undertaken for decades, if not centuries ${ }^{8}$ and seem to be countless. This essay thus does not aim at further developing this broader concept, but intends to identify problematic aspects and to determine what might be commonly agreed upon to be denoted by this term, at least in the European Union (EU). The presumably first problem regarding the wording which focusses on the state can be relatively easily resolved, as today the German legal terminology allows a broad interpretation of Rechtsstaatlichkeit, thus enabling the use of this term for the EU (see Article 2, Treaty on European Union - TEU in the German language) and other international organisations. ${ }^{9}$ In addition, the ECJ chooses the term "community based on the rule of law"10.

In short, Rechtsstaatlichkeit describes "a state that is governed by law", i.e., by previously existing rules and norms ${ }^{11}$ This short definition indicates the aim of the principle, which is to achieve a certain order, providing predictable relations and thus maintain a stable, plannable environment. Those addressed by the law may arrange their behaviour according to existing norms and adjust their respective relations. In the ideal case of the rule of "good (i.e.: just and fair) law" leads to a society that accepts the governing rules and norms, lives in accordance with them and the entity of rules hence provides the framework for peace and stability of a state.

The same may be said about the "rule of law". This term describes a situation which is governed by law, i.e., previously existing rules and norms, though, linguistically, it is not limited to states but may also apply to international organisations.

Central to both definitions seems to be the equation of Recht resp. law with "rules and norms". In reality, however, the situation is more complex, as it raises the fundamental philosophical question, what is Recht [in German language simultaneously meaning a right and law, but also implying something just or fair]? The relevance of this question becomes clearer in the light of a more differentiated approach on the essence of the term Rechtsstaat. German legal science distinguishes between substantive [materielle] and formal [formelle] Rechtsstaatlichkeit. In essence, this distinction signifies that the latter refers to compliance with the - mostly written - law, whereas materielle (substantive) Rechtsstaatlichkeit particularly addresses the aspect of Gerechtigkeit (lit. translated as justice, however, the German term is rather expressed by the concepts of fairness and equity). Accordingly, the German constitution in Article 20(3) GG distinguishes between law and justice ("The legislature shall be bound by the constitutional order, the executive and the judiciary by law and justice"). The difference between these aspects and the interest of a distinction has frequently been highlighted and the debate identified a problem

8 In detail Trentmann, C. Die Grundlagen des Rechtsstaatsbegriffs - Zugleich eine Einführung in die Rechtslehre Immanuel Kants und Robert von Mohls. Juristische Schulung, Nr. 10, 2017, S. 982; Grzeszick, B. Article 20. Bundesstaatliche Verfassung; Widerstandsrecht. In: Maunz, T., Dürig, G. Grundgesetz-Kommentar, VII, p. $3 \mathrm{f}$.

9 Hilf, M., Schorkopf, F. Article 2 EUV. In: Grabitz, E., Hilf, M., Nettesheim, M. Das Recht der Europäischen Union, S. 37.

10 Judgement of ECJ of 23 April 1986 in case No. 294/83, p. 23. Available: https://eur-lex.europa.eu/ legal-content/EN/TXT/?uri=CELEX:61983CJ0294 [last viewed 01.10.2021].

11 Voßkuhle, A., Kaufhold, A.-K. Grundwissen - Öffentliches Recht: Das Rechtsstaatsprinzip. Juristische Schulung, Bd. 50, H. 2, 2010, S. 116. 
which may be formulated in the form of a question: Can written law, which obviously leads to manifest injustice still be regarded as law, only because it has been enacted in accordance with the constitutional requirements? Formally, we may perfectly speak of Recht (the German Recht seems to comprise the two notions, law and justice and thus seems to indicate that law is just in the sense of fair), in reality, however, the Recht (law) appears to be Unrecht (literally meaning "unlawful", although in this sense rather meaning: "unjust"). ${ }^{12}$ Or, as the controversial legal scholar Carl Schmitt put it in 1935, the concept of the Rechtsstaat itself is void of any specific content. ${ }^{13}$ Rechtsstaat, according to this formal concept, thus merely amounts to a state, governed by [any kind of] laws. This aspect has also been raised in the context of the German reunification in more popular language: "Wir wollten Gerechtigkeit und bekamen den Rechtsstaat!" [The translation: "We wanted justice and finally got the rule of law!" probably comes closest to the original meaning]. ${ }^{14}$ The concept of materielle Rechtsstaatlichkeit addressed this problem, as it, in addition to the formal rule by law, strives to providing substance in the sense of justice and fairness. This aspect, i.e., the question, what is supposed to be fair, also comprises philosophical, ethical and political dimensions that lead to views which may, furthermore, vary geographically and over time. In addition, the respective answer to the question, what is to be understood as fair, differs according to the perspective of the subject concerned. Accordingly, the same situation might be considered differently, e.g., whether a scheme of progressive taxation or a flat tax of $25 \%$ is fair for the taxation of millionaires and poor people. ${ }^{15}$ Moreover, the definition of legal terms which require the interpretation of their meaning may lead to quite different outcomes in legal practice. One of the most relevant examples in the context of this article concerns the meaning of "common values" in Article 2 TEU.

At first glance, the term of "common values" may insinuate an identical meaning in the various Member States. Nevertheless, the notion is broad and needs to be further elaborated and interpreted, which thus renders it susceptible to manipulation. However, the positioning in Article 2 TEU illustrates the uttermost importance of these values for the EU and its legal system. ${ }^{16}$ Literally overarching

12 Unfortunately, present political developments provide various examples, where this aspect might be discussed. Relevant references may be found everywhere in the free press worldwide. For reasons of simplicity, we merely refer to one issue of The Economist, April $17^{\text {th }}-232021$, describing, for instance, the situation in Myanmar (pp. 13, 40), where the military pretends to act in accordance with national law; in Hongkong, where the PRC argues that imprisonment of activists was in line with the rule of law (more or less on p. 44) or Russia, which claims to act in line with the existing law when imprisoning Aleksei Nawalny or regarding the activities of Russian military in the Ukraine / at the Ukrainian border (p. 20). Beyond these dramatic examples, it is also possible to identify situations in liberal countries of a more a limited and minor impact, which, however, may also illustrate a discrepancy between law and what is conceived as fair (or just), for instance, the example of "Containering" in Germany, shows, see Judgement of the Constitutional Court of the Federal Republic of Germany of 5 August 2020 in case No. 2 BvR 1985/19, 2 BvR 1986/19. Available: https://www.bundesverfassungsgericht.de/SharedDocs/ Entscheidungen/DE/2020/08/rk20200805_2bvr198519.html [last viewed 14.05.2021].

13 Schmitt, C. Was bedeutet der Streit um den „Rechtsstaat“" Zeitschrift für die gesamte Staatswissenschaft, Bd. 95, H. 2, 1935, S. 196).

14 To that Bahners, P. Bärbel Bohley: Gerechtigkeit und Rechtsstaat. Frankfurter Allgemeine Zeitung, 14.10.2020. Available: https://www.faz.net/aktuell/feuilleton/debatten/baerbel-bohleys-zitat-vongerechtigkeit-und-rechtsstaat-16996571.html [last viewed 01.10.2021].

15 Braun, J. Einführung in die Rechtswissenschaft, Mohr Siebeck, 4. Aufl, Tübingen, 2011.

16 Bogdandy, A. von. Tyrannei der Werte? Herausforderungen und Grundlagen einer europäischen Dogmatik systemischer Defizite. Zeitschrift für ausländisches öffentliches Recht und Völkerrecht, Bd. 79, H. 3, 2019, S. 512 ff. 
the EU legal and political system, the common values comprise the essence of the philosophic and humanistic European heritage ${ }^{17}$ which guide the subordinated polity objectives stipulated in Article 3 TEU. Accordingly, they are supposed to express the essence of the EU fundamentals, a function which simultaneously burdens them with an extensive field of application. This makes values appear differently, according to the context in which they stand, resembling "shimmering in different colours according to the incidence of light". This somewhat poetic comparison illustrates the problem that values may vary according to the position of the observer, given that values are subject to the perspective and position of those referring to them. ${ }^{18}$ Notwithstanding their importance, the complexity of their nature thus makes the term open to diverging interpretations. Subsequently, one may observe that the description of values may vary according to those who direct the rule of interpretation (Definitionsherrschaft). Furthermore, nuances of interpretation may considerably affect the subordinated law and thus have repercussions on the (European and national) political debate. Eventually, the process of interpretation may become the subject of debates and disputes which frequently are of a political nature.

Moreover, it is important to take note of a considerable diversity among the different political systems of Member States. They may be republics or monarchies with parliamentary and semi-presidential systems with powerful und powerless parliaments, democracies with powerful parties, organised in centralistic and federal systems, powerful, powerless and missing constitutional courts, as well as differences in fundamental rights. ${ }^{19}$

In the light of these aspects, it is problematic to assume that all $27 \mathrm{EU}$ Member States with their singular national histories adhere to identical values - and apply an identical concept of the materielle Rechtsstaatlichkeit (rule of law in its substantive sense) - which would suggest one single approach in the EU. On the contrary, the openness and lack of precision of the term "values" - including the value "rule of law" - is subject to different understandings in the Member States.

The potential diversity, reflected in different approaches to values and the concept of the rule of law, may lead to practical problems which are particularly manifest in the aspects of the materielle Rechtsstatlichkeit. These considerations illustrate that this very concept, which aims at providing fairness and equity, may potentially contradict one of the main aspects of Rechtsstaatlichkeit, namely, its aim to provide legal security, clarity, and predictability.

The concept of the substantive rule of law thus potentially bears an inherent conflict of the aims, legal security and fairness, which, in some instances, may stand detrimentally to another. This dilemma had famously been discussed by the legal philosopher Gustav Radbruch some 70 years ago (1946), after the reign of terror by the National Socialists which is also known as the Radbruchsche Formel:

The resolution of the [possible] conflict between justice and legal certainty may well be found in a formula such as this: Preference is given to the positive law, duly enacted and secured by state power as it is, even when it is unjust and fails to benefit the people, unless its conflict with justice reaches so intolerable a level that the statute becomes, in effect, 'false law' and must therefore yield to

17 Recital 2 of the Preamble TEU.

18 Von Bogdandy illustrated this aspect when referring an important Germany Commentary (Dreier) on the term "Rechtsstaat" which spans 200 pages. Bogdandy, A. von. Tyrannei der Werte?, S. 542.

19 Bogdandy, A. von. Tyrannei der Werte?, S. 543. 
justice. [..] One line of distinction, however, can be drawn with utmost clarity: Where there is not even an attempt at justice, where equality, the core of justice, is deliberately betrayed in the issuance of positive law, then the statute is not merely 'false law', it lacks completely the very nature of law. For law, including positive law, cannot be otherwise defined than as a system and an institution whose very meaning is to serve justice. ${ }^{20}$

This conclusion seems to indicate a certain degree of impuissance and to suggest surrendering to the factuality of reality. However, even though there is no simple comprehensive theory to this problem, there seems to be a broad consensus that there are core principles that have been identified as elements of an internationally accepted notion of the rule of law. In fact, for measuring the rule of law and for implementing respective standards in countries of transition, scholars and practitioners from different continents and legal systems have undertaken various approaches for contributing to the rule of law. ${ }^{21}$ Most of these initiatives have established catalogues of elements that may be seen as constitutive for the rule of law. Some of these elements may still be contested or be less applicable to some states or societies than others; however, the following aspects may be identified and regrouped. The Venice Commission ${ }^{22}$ counts five core elements of the Rule of Law: ${ }^{23}$

Firstly, legal certainty concerns the accessibility of the law. The law must be certain, foreseeable and easy to understand. Secondly, the principle of legality implies that administration and courts are bound by the law and that decisions and acts are based on a (sufficiently precise) legal basis for the action of the executive, at least in central areas, as well as the demand for measurability of state behaviour with the specifics of sufficient clarity, proportionality and legal certainty, i.e., limited retroactive effect and protection of legitimate expectations - the legal reservation (Article 52 (1) 1 CFR). This also implies a functioning private legal system including a judicial infrastructure.

A third task aims at preventing the abuses of powers which ensures that the legal system provides safeguards against arbitrariness and that the discretionary power of the officials is not unlimited, and it is regulated by law.

A fourth element requires control and review, i.e., the separation or a balance of power in order to ensure a system of "checks and balances", as well as an independent judiciary (Article 19(2) subpar. 3 sentence 1 TEU). Furthermore, it comprises the protection of fundamental rights, including effective legal protection ${ }^{24}$ with the principle of proportionality ${ }^{25}$, the fundamental right to good administration and Equality before the law and non-discrimination. According to this principle, similar situations must be treated equally and different situations

20 Radbruch, G. Gesetzliches Unrecht und übergesetzliches Recht. Süddeutsche Juristenzeitung, Nr. 1, 1946, S. 107; translation copied from: Leawoods, H., Radbruch, G. An Extraordinary Legal Philosopher. WASH. U. J. L. \& POL'Y. Vol. 2. Re-Engineering Patent Law: The Challenge of New Technologies, January 2000, p. 500. Available: https://openscholarship.wustl.edu/cgi/viewcontent. cgi?article=1516\&context=law_journal_law_policy [last viewed 01.10.2021].

21 United Nations. Available: https://www.un.org/ruleoflaw/thematic-areas/justice-2/; World Bank. Available: https://www.worldbank.org/en/topic/governance/brief/justice-rights-and-public-safety.

22 Venice Commission of the Council of Europe, Rule of Law Checklist. Available: https://www.venice. coe.int/webforms/documents/default.aspx?pdffile $=$ CDL-AD(2016)007-e [last viewed 14.05.2021].

23 These elements are copied from: https://www.venice.coe.int/WebForms/pages/?p=02_Rule_of_ law\&lang=EN [last viewed 12.05.2021].

24 Article 51(1) CFR, Article 47 CFR, Article 19(1) subpar. 2 TEU.

25 cf. Article 5(1)2 and (3)1 and (4) TEU; Article 52(1)2 CFR. 
differently. Positive measures could be allowed as long as they are proportionate and necessary.

Finally, the fifth aspect concerns access to justice, which implicates the presence of an independent and impartial judiciary and the right to have a fair trial. The independence and the impartiality of the judiciary are central to the public perception of the justice and thus to the achievement of the classical formula: "justice must not only be done, it must also be seen to be done". These aspects comprise accountability and state liability.

While it is too much to assume that all $27 \mathrm{EU}$ Member States with their independent national histories adhere to identical values and standards which would suggest one single approach - as for instance the rule of law - for all, the constitutional traditions of the Member States nonetheless have a common nucleus that leads to a community of values. These traditional values are incorporated in the European Treaties (Article 2, 7 und 49 TEU) in which all Member States committed themselves to promoting them. Accordingly, the legislative branch of the European Union depends on Member States that execute law based on European values.

\subsection{Safeguarding the Rule of Law Under the Treaties and Article 7 TEU}

When concluding the Treaties, Member States had agreed to ensure the rule of law in the European Union. This may be observed in the different procedures, such as the preliminary ruling procedure (Article 267 TFEU), infringement proceedings (Article 258 und 259 TFEU) and also in the procedure stipulated in Article 7 TEU regarding the breach of values. In addition to these "hard-law" instruments, the European Parliament and the Council agreed on a general regime of conditionality for the protection of the Union budget in December 2020. In contrast to the abovementioned procedures, these new instruments aim at preventing a breach of the rule of law, respectively, its continuation, leaving it to the Member States to restore the rule of law.

The sanction procedure according to Article 7 TEU serves - regardless of context - to enforce the canon of values according to Article 2 TEU. Article 7(1) TEU requires a clear risk of a serious breach of the values specified in Article 2 TEU by a Member State. A breach of an aspect of the rule of law (or a corresponding danger ${ }^{26}$ ) is generally not sufficient. Rather, Article 7(1) TEU speaks of a "serious" breach, Article 7(2) TEU of a "serious and persistent breach". These aspects are comprised by the term systemic deficit which requires an overall assessment of all measures, taking due account of the political and social conditions in the Member States reviewed. This may, for instance, be assumed in the case of repetitive illegal acts, if these are rooted deeply in state structures or if they were ordered by the highest authorities, expressing a political line. The provision requires a certain intensity, however, already a single incident, such as breaking a taboo - as a single case of torture - may indicate a systemic deficit if there is no adequate institutional response. Furthermore, there is a strong presumption of a systemic deficit if widespread corruption calls the implementation of Union law into question. This is, for instance, the case, if it is not ensured that the law will be applied (correctly) or if the courts can no longer be expected to independently review governmental acts. ${ }^{27}$

As to the legal consequences, Article 7(3) TEU allows the Council to suspend certain rights deriving from the application of the treaties to the EU Member State

26 Bogdandy, A. von. Tyrannei der Werte?, S. 523.

27 Ibid., S. $525 \mathrm{ff}$. 
in question, including its voting rights in the Council. In that case, however, the "serious breach" must have persisted for some time and it is to highlight that the provision does not foresee financial sanctions. Moreover, this procedure is regarded as the last resort in order to preserve the very core of European values.

The procedure firstly foresees a Council hearing of the Member State concerned, which may lead to respective recommendations. The procedure, however, requires unanimity the European Council on a proposal by one third of the Member States or by the Commission and after obtaining the consent of the European Parliament.

Given that the procedural requirements are exceptionally high, the provision has only been used in a few cases. First of all, it is difficult to achieve unanimity among 26 Member States in a sanction procedure against a single and - in this case, isolated - Member State. Furthermore, as to the substantive law, it is difficult to establish the corresponding breach or the clear risk in a sovereign Member State. Finally, the sanctions tend to have an effect which is contrary to the EU's aim of integrating Member States. Consequently, the Article 7 TEU procedure has been described as the "nuclear option"28 (José Manuel Barroso) with a "symbolic function" 29 .

\subsection{The Conditionality Mechanism Under Regulation 2020/2092}

The regulation enacting the so-called "Conditionality / Rule of Law Mechanism"30 or, officially, the "Regulation on general conditional rules for the protection of the budget of the Union" entered into force on 11 January 2021. ${ }^{31}$ It consists of ten articles which deal with three thematic aspects: Firstly, defining the scope of the regulation, secondly, dealing with definitions and a third thematic aspect concerns breaches. Finally, the regulation lays down the conditions and measures to be adopted, the relevant procedure, as well as the requirements for their lifting.

\subsubsection{The Substantive Elements of the Regulation - Breaches of the Rule of Law}

Article 4 of the regulation specifies the substantive requirements for the rule of law mechanism. Legal consequences may be triggered, if the principles of the rule of law in a Member State (2.3.1.1) are breached (2.3.1.2.), which impairs or seriously jeopardizes the proper financial management of the Union or jeopardizes the protection of the Union's financial interests in a sufficiently direct manner (2.3.1.2.).

\subsubsection{Rule of law principles}

Article $2 \mathrm{a}^{32}$ seeks to define the rule of law, as follows:

[..] 'the rule of law' refers to the Union value enshrined in Article 2 TEU. It includes the principles of legality implying a transparent, accountable, democratic and pluralistic law-making process; legal certainty; prohibition of arbitrariness of the executive powers; effective judicial protection, including

28 Quoted after Schorkopf, F. Wertesicherung in der Europäischen Union. Prävention, Quarantäne und Aufsicht als Bausteine eines Rechts der Verfassungskrise? Europarecht, Nr. 2, 2016, S. 150.

29 Ibid.

30 European Commission, Rule of law mechanism. Available: https://ec.europa.eu/info/policies/ justice-and-fundamental-rights/upholding-rule-law/rule-law/rule-law-mechanism_en [last viewed 01.10.2021].

31 Regulation (EU, Euratom) 2020/2092 of the European Parliament and of the Council of 16 December 2020 on a general regime of conditionality for the protection of the Union budget. OJ, L 433I, 22.12.2020, pp. 1-10.

32 If not otherwise indicated, the following articles quoted refer to regulation 2020/2092. 
access to justice, by independent and impartial courts, also as regards fundamental rights; separation of powers; and non-discrimination and equality before the law. The rule of law shall be understood having regard to the other Union values and principles enshrined in Article 2 TEU;

The norm thus provides a list of non-exclusive aspects, which indicate imperative requirements of the rule of law. However, this implies that further aspects may be required for establishing the rule of law.

\subsubsection{Breaches}

The mechanism aiming to ensure the rule of law is stipulated in Article 3 of Regulation 2020/2092, as it may be triggered by breaches of the principles of the rule of law. The following may be indicative of breaches:

[..]

(a) endangering the independence of the judiciary;

(b) failing to prevent, correct or sanction arbitrary or unlawful decisions by public authorities, including by law-enforcement authorities, withholding financial and human resources affecting their proper functioning or failing to ensure the absence of conflicts of interest;

(c) limiting the availability and effectiveness of legal remedies, including through restrictive procedural rules and lack of implementation of judgments, or limiting the effective investigation, prosecution or sanctioning of breaches of law.

The wording "the following may be indicative of breaches" implies that the norm either requires a breach of the explicitly pronounced rule of law principles or of aspects that are considered as equivalent breaches of this principle..$^{33}$ Given that the wording of Articles 3 and 4 is formulated in the plural, it leads to conclusion that a single breach is not sufficient to constituting a breach. The breach of one of these aspects automatically triggers legal consequences, as the provision does not foresee any further requirements. However, the Member State under review may undertake refuting the suggestion that the act breaches the rule of law. Even though the list of rule-of-law elements is not exclusive, there is a (refutable) assumption that state measures, which do not constitute a breach of these explicit elements of Article 3 , comply with the rule of law. Accordingly, the hurdles are considerably higher, when it is attempted to prove a breach of the rule of law in case of the non-written elements.

\subsubsection{Damage or Serious Threat to the Proper Financial Management of the Union or the Protection of the Union's Financial Interests}

For assuming a breach, the regulation further requires that the sound financial management of the Union or the protection of the Union's financial interests is impaired or seriously jeopardized. In this respect, the regulation rather appears to protect the EU budget than the rule of law. To a certain extent, this formulation also expresses the importance of the rule of law for the EU, as financial aid by the

33 Contrary to this reading, the European Council stated in point f): "The triggering factors set out in the Regulation are to be read and applied as a closed list of homogenous elements and not be open to factors or events of a different nature. The Regulation does not relate to generalised deficiencies". EUCO 22/20 CO EUR 17 CONCL 8, 11 December 2020. 
$\mathrm{EU}$ is only granted under a lawful procedure in the sense of this regulation. As the regulation requires a prejudice to the Union's financial interests, the term "rule of law mechanism" falls short, given that breaches of the rule of law in Member States without the respective prejudice cannot be sanctioned under this regulation. ${ }^{34}$ However, one may take note of the CJEU case law on this element of similar secondary law acts, which is usually interpreted in an extensive manner and that "[..] a demonstration of the existence of a specific financial impact is not required. It is sufficient that the possibility of an impact on the budget of the funds concerned is not excluded." 35

\subsubsection{Legal Consequences}

If the aforementioned requirements are met, Article 5 provides for various legal consequences. Article 5(1) differentiates between the legal consequences according to whether the Commission implements the Union budget in accordance with Article 62(1) points (a) and (c) of the financial regulation. Unlike the procedure under Article $7 \mathrm{TEU}$, the regulation provides for financial sanctions. In particular, the following sanctions are envisaged: the suspension of payments in whole or in part; the prohibition on entering into new legal commitments; the suspension of commitments and payments; the reduction of commitments, including through financial corrections or transfers to other spending programmes; the reduction of pre-financing or the interruption of payment deadlines.

Ultimately, Article 5(3) of the regulation stipulates that the measures must be proportionate, thus prescribing that the procedure itself is based on the rule of law. This requirement is specified in more detail in Article 6(1) and (5), Article 5(3) sentence 3 specifies that measures must be suitable, i.e., the nature, duration, gravity and scope of the breaches of the principles of the rule of law shall be duly taken into account. The measures cannot therefore be used to sanction purely domestic breaches of the rule of law. Furthermore, the measures must also be necessary. Article 6(1) expressively provides that a dialogue may be regarded as a milder measure of equal effectiveness.

Finally, the nature, duration, severity, and scope of the breaches of the rule of law must be duly taken into account when considering whether a measure is appropriate (Article 5(3), sentence 2).

\subsubsection{Procedure}

Article 6 to Article 8 provide for additional requirements regarding the procedure, not least in order to preserve its legitimacy. While the mechanism has been criticised for being a "toothless tiger" 36 , this statement fails to recognize that this procedure, in turn, also has to comply with the principles of the rule of law. ${ }^{37}$

34 This passage of the regulation has therefore been heavily criticised, see supra note 4.

35 See for instance CJEU, C-408/16 para. 60 u. 61 (Compania Națională de Administrare a Infrastructurii Rutiere) ECLI:EU:C:2017:940 and C-743/18 (LSEZ SIA/Latvijas Investīciju un attīstības aǵentūra) with further references in para. 66.

36 Mader, O. Rechtsstaatlichkeit und Haushalt: Der Stand des Werteschutzes in der EU nach dem Streit über die Rechtsstaatsverordnung. Europäische Zeitschrift für Wirtschaftsrecht, Bd. 32, H. 4, 2021, S. 133.

37 See CJEU, C-743/18 (LSEZ SIA/Latvijas Investīciju un attīstības aǵentūra) and comments by Schewe, C. EuGH: Investitionen: Verstoß gegen eine Unionsbestimmung als Folge einer Handlung eines Wirtschaftsteilnehmers. Europäische Zeitschrift für Wirtschaftsrecht, Bd. 32, H. 3, 2021, S. 119. 
Article 6 deals with the procedure and stipulates that the Commission investigates the matter and, if applicable, submits a proposal for an implementation of decision on the appropriate measures to the Council.

According to Article 6(5), the Member State must be heard beforehand on the findings that form the objective basis for the measures proposed by the Commission. At a later point in time, according to Article 6(7), there is also the possibility of expressing a view on proportionality. In particular, the Member State has the option of proposing remedial measures in accordance with Article 7. Objections raised to this, that it would be appropriate to give the concerned Member States time and further blocking possibilities, ${ }^{38}$ are not convincing for reasons of the rule of law (cf. Article 41(2) lit. a CFR). Hereafter, the Commission submits a draft implementing decision with appropriate measures to the Council which may adopt it or change it by qualified majority.

Article 7 regulates the procedure for the lifting of measures. Thereafter, one year after the adoption of measures at the latest, the Commission will examine the situation in the Member State concerned.

According to Article 8, the Commission informs the European Parliament immediately of all the measures proposed, adopted or repealed under Articles 5, 6 and 7 and reports to the European Parliament and the Council on the application of this regulation, in particular on the effectiveness of the measures taken.

\subsubsection{The Essentials of the Regulation - Positive Elements and Shortcomings}

Overall, the regulation establishes the very essentials of the internationally accepted core elements of the rule of law. Furthermore, the regulation itself expressively foresees that its procedure respects these standards, i.e., in sum, one may regard Article $2 \mathrm{TEU}$ as as a written minimum of the essence of the rule of law. With regard to the inherent problems that this principle brings along, it was improbable to expect more of the definition. This concerns e.g. the initial proposal by the Commission, to also incorporate the term "generalised deficiencies", which would have been problematic under this very principle, due to a lack of precision. However, when it comes to the Article 3, one needs to take note of the massive criticism this provision has encountered, not only concerning the necessary link to the budget, but particularly regarding the watering down of the legal mechanism through additional steps implying the European Council that, eventually delay the process. Regarding the overall outcome, one may thus quote the catchy conclusion by Dimitrovs and Droste that "[..] Brussels apparently obtained what it is best at: it reached a compromise that makes everyone equally unhappy." 39 However, these clarifications have not yet explained, whether the substantive content of regulation in fact collides with national identity as has been voiced by the Polish and Hungarian governments.

\section{Polish and Hungarian Concerns: EU Law v. National Identity?}

At first glance, the regulation does not seem to introduce anything surprising or new: overall, the definition of the term is not really novel and widely resembles the earlier definitions. Furthermore, all Member States are bound by the principles

38 Mader, O. Rechtsstaatlichkeit und Haushalt, S. 133 (139).

39 Dimitrovs, A., Droste, H. Conditionality Mechanism: What's In It? VerfBlog, 30.12.2020. Available: https://verfassungsblog.de/conditionality-mechanism-whats-in-it/ [last viewed 01.10.2021]. DOI: $10.17176 / 20201230-201659-0$. 
stipulated in Article 2 TEU, which explicitly addresses the rule of law. ${ }^{40}$ This raises the question, why two governments so strongly opposed against this conditionality mechanism and whether their concerns are well-founded.

\subsection{Polish and Hungarian Concerns}

The Polish and the Hungarian governments uttered their concerns ${ }^{41}$ against this new mechanism. Their arguments are partially political and partially legal and may be regrouped in three categories. ${ }^{42}$ First of all, the two states argue that the regulation interferes with the competence of the Member States, i.e., breaches the principle of conferral, and that the provisions of the Treaty, namely, Article 7 TEU procedure, were exclusive. Secondly, that the broad criticism towards the two states was unfounded, given that other Member States (too) show rule of law-deficiencies. Thirdly, particularly Hungary counters the allegations regarding corruption and financial abuse of funds with a statement that all subsidies had been legally obtained and spent in accordance with EU rules.

\subsubsection{The Various Arguments Against the Regulation Regarding a Lack of EU Competence}

The first set of arguments concerns various political aspects that imply a legal reasoning, as the two governments refer to lack of EU competence. Both claim that the states acceded to the EU without the intention to become members of a federalist union. Furthermore, it was under the discretion of the Member State to independently regulate family and matrimonial matters, - the Member State was free to decide on questions of immigration and asylum and national security remained the sole responsibility of each Member State. ${ }^{43}$ Moreover, the Polish Minister for European Affairs emphasized the right of each Member State to organize its judicial system autonomously. Finally, they argue that the respective national legal acts reflect the due exercise of democracy and national identity or values.

\subsubsection{Pointing the Finger at Other Member States}

In the second line of argumentation, the two states claim that other Member States (also) breach the rule of law. This contention is probably directed against Germany (and others), where prosecutors are under the direction of the Ministry of Justice and judges are appointed by politicians, secondly, that some Member State were not able to protect Christians or Jews from (Islamist/Muslim) acts of aggression.

40 Gutscher, T. Polen und Ungarn klagen gegen EU-Rechtsstaatsmechanismus. 11.03.2021. Available: https://www.faz.net/aktuell/politik/ausland/polen-und-ungarn-klagen-gegen-eu-rechtsstaatsmecha nismus-17238896.html [last viewed 01.10.2021].

41 Löwenstein, S. Es geht um Erpressung. FAZ. 17.11.2020. Available: https://www.faz.net/aktuell/ politik/ausland/ungarns-justizministerin-varga-es-geht-um-erpressung-17056871.html [last viewed 01.10.2021].

42 The argumentation of the two states is not identical, however, in order to systematically illustrate the various aspects playing a role in the debate, they are presented jointly.

43 https://www.cicero.de/aussenpolitik/interview-mit-dem-ungarischen-parlamentsprasidenten-laszlokover-ungarn-bleibt-solange-mitglied-der-union-bis-diese-zusammenbricht. Varga, J. „Sind wir das schwarze Schaf, weil wir keine Migration wollen?“. Die Welt. 13.11.2020. Available: https://www.welt. de/politik/ausland/plus220037090/Ungarn-Wir-wollen-keine-multikulturelle-Gesellschaft.html [last viewed 01.10.2021]. 


\subsubsection{Correct Spending of EU Funds}

This aspect particularly concerns the allegations against Hungary that its government misuses EU funds, especially in order to build up an illiberal media landscape. The government, however, denies doing so.

\subsection{The Legal Foundation of the Polish and Hungarian Concerns}

It has previously been indicated that these political arguments to a certain extent have a legal basis in the treaties. The first set of argumentation refers to the aspects of competence, namely, the principles of conferral and subsidiarity (see Article 4 and 5(1) and (3), 13 TEU), which is also reflected in the two Member States' claims. ${ }^{4}$

However, the argument concerning democracy and national identity contains a debatable reasoning in that, according to the concept of Article 2 TEU, these values are not supposed to conflict with the rule of law, but are mutually dependent: the rule of law serves to implement democratic politics. Resolutions of the (Polish) parliament can only be implemented in accordance with the aforementioned core principles of the rule of law. Lack of transparency, corruption and arbitrariness would run counter to the democratic decisions of the (Polish) parliament. In this respect, the rule of law safeguards "the core of the core" of European values. Apart from Article 2 TEU, it is important to note that this principle also forms an outstanding value of the constitutions of all Member States, including the Polish Constitution (Article 2, Constitution of the Republic of Poland). Furthermore, the rule of law in the independent Member States is a conditio sine qua non for becoming a member in a supranational organization like the EU and to jointly exercise the pooled sovereignty of Member States. This means that the EU, in the areas of the competences conferred, exercises supranational power, which necessarily implies that the Member States agree not to exercise state power in these areas. This aspect of supranationality, however, does not mean that the EU will become a federal state but that the EU may legislate according to the treaties. In this regard, it is vital that the EU and its Member States can be certain that the enacted law will be applied and that this application will be monitored by independent courts. If this were not ensured, the legal order would lack efficiency and jeopardise the whole existence of the supranational organization and reduce the EU to an international agreement.

These considerations imply a high level of mutual loyalty among the Member States, which therefore is enshrined in Article 4(3) TEU. Furthermore, the EU is based on the principle of mutual recognition of administrative and judicial decisions. The acts of foreign sovereignty, however, may only be recognized and enforced by a Member State against its own citizens if they essentially meet comparable requirements. Accordingly, Member States are bound by the values of Article 2 TEU when designing their internal structures. This implies that the design - or concept - of national identity, which is based on national "building laws", must yet heed a few "red lines"45 respecting the values of Article 2 TEU. While this is not to be confused with levelling national or cultural identities, successful integration nevertheless requires a certain degree of homogeneity of constitutional values. ${ }^{46}$ Subsequently, the regulation is limited to reviewing whether

44 C-156/21, see supra note 7.

45 Bogdandy, A. von. Tyrannei der Werte?, S. 503 (543).

46 Schorkopf, F. Wertesicherung in der Europäischen Union, S. 148. 
administration and jurisprudence are based on the rule of law. The regulation does not deal with family and matrimonial matters or questions of immigration and asylum, thus respecting the principle of subsidiarity.

The second line of political arguments, however, seems to be irrelevant from a legal perspective, even if the claims are well founded. The defense along the lines "we only do what others are doing" is frequently employed by these two Member States. ${ }^{47}$ According to a principle of international law, already known in Roman law as ex iniuria ius non oritur, there is no right to equal treatment in the case of illegality (literally, "law (or right) does not arise from injustice"). This principle must necessarily apply for the EU, since, otherwise, unsanctioned breaches of the various EU Member States would accumulate and continuously lead to a decrease of the rule of law. Notwithstanding, blaming other Member States might have consequences, as the rule of law and the application of the regulation would make it necessary to also initiate infringement procedures against those Member States, that are encroaching with the corresponding rules. In the case of Germany ${ }^{48}$ and Portugal ${ }^{49}$, this has already been the case.

In the supranational interest, only those breaches are to be sanctioned that affect the economic management of the Union's budget or the protection of its financial interests in a sufficiently direct manner, or threaten to seriously affect it. If these requirements are met, no Member State is immune to a corresponding procedure, ${ }^{50}$ which illustrates that the regulation cannot be considered as "lex Hungary and Poland".

The third set of arguments implies a complex analysis of the corresponding law, which thus defers any preliminary comment or quick answer. ${ }^{51}$ The wider field of the funds and subsidies is relatively technical and, over the decades, has been regulated in detail. For that reason, problematic cases need to be reviewed independently on the grounds of the specific governing law by independent, specialized institutions and agencies. Their findings are subject to independent legal review and finally, the CJEU in constant practice has further developed the corresponding law on the correct administration of EU funds in neighbouring fields, such as government procurement.

Accordingly, particularly the first set of questions may require a legal review of the corresponding legal acts by the CJEU. However, it must yet be examined how far these aspects concern the validity of the regulation.

\section{Summary}

As the result of a compromise between the 27 Member States, the new rule of law mechanism or the conditionality mechanism aims at protecting the core elements

\footnotetext{
47 See the Polish White Paper on the reform of the judiciary. Available: https://www.statewatch. $\mathrm{org} / \mathrm{media} /$ documents/news/2018/mar/pl-judiciary-reform-chanceller-white-paper-3-18.pdf; Supreme Court opinion on the White Paper on the reform of the judiciary. Available: https:// archiwumosiatynskiego.pl/images/2018/04/Supreme-Court-Opinion-on-the-white-paper-on-theReform-of-the-Polish-Judiciary.pdf; https://verfassungsblog.de/solving-the-copenhagen-dilemma/.

48 CJEU, C-508/18, 27.05.2019.

49 CJEU, C-64/16, Associação Sindical dos Juízes Portugueses, Judgment of the Court of Justice, 27 February 2018, EU:C:2018:117.

50 See the Rule of law report in every Member State. Available: https://ec.europa.eu/info/policies/justiceand-fundamental-rights/upholding-rule-law/rule-law/rule-law-mechanism_en.

51 Györy, C. Ein Freund, ein guter Freund. VerfBlog. 22.12.2020. Available: https://verfassungsblog.de/ ein-freund-ein-guter-freund/ [last viewed 01.10.2021]. DOI: 10.17176/20201222-172713-0.
} 
of the rule of law. In its substance, it transcends the concept of a merely formal rule of law (formelle Rechtsstaatlichkeit), given that it provides certain set standards. Insofar as it aims at ensuring legality, legal certainty, prohibition of arbitrariness, judicial protection by independent impartial courts, also as regards fundamental rights, separation of powers and non-discrimination before the law (see Article 2 lit. a), it is comparable to other standards applied internationally. Comprising only these aspects of the rule of law, it, however, does not aim at providing justice or fairness, in the sense of a substantive understanding of the rule of law. While for some this aspect will be considered as a deficiency, others may be relieved, given that the mechanism does not aim at regulating aspects that might be considered as cultural or national identity. Be it as it may, the respective concerns uttered by the Polish and Hungarian governments against the substance of the mechanism thus appear to be unfounded.

With regard to increasing tensions, where a number of states deplored the decrease of the rule of law in a few Member States and the lack of instruments that may safeguard the values of the EU enshrined in Article 2 TEU, the mechanism may at least be seen as a positive step. In the sense of "better than nothing", it can generally be regarded as a good and novel tool. Moreover, the Regulation enriches the variety of instruments under EU law with a milder and more flexible alternative for sanctioning the Member States disrespecting the rule of law. ${ }^{52}$ This again needs to be seen as an advancement compared to using "the nuclear weapon", i.e., Article 7 TEU, which has proved to be too rigid and severe.

This said, it should be remembered that this codification securing the rule of law only clarifies what probably most have taken for granted: that upon joining EU, all the Member States have agreed to respect the values of Article 2 TEU. ${ }^{53}$ In this regard, it is a clear negative signal of the political development in the EU, that it has become necessary to establish these more rigorous legal instruments. Furthermore, it might be said that strict instruments do not create trust, which is important for deeper integration. Apart from this general aspect of criticism, there is a number of problematic issues ${ }^{54}$ that have been addressed, and that will not be repeated here in detail. However, this overview has shown that the rule of law comprises a variety of aspects that bring together different legal principles which require careful balancing, simultaneously underscoring the need for mutual trust and loyalty among the actors. For the EU, this means that the principle of the rule of law needs to be taken seriously and respected by all, - Member States and the EU alike. While this essay has particularly pointed at deficiencies in legal and political practice in Hungary and Poland, this does not mean that all other Member States comply with this principle immaculately. Also, Germany, where politicians frequently reminded other states of the necessity to "do their homework" 55 , was found to disrespect the principle of independent prosecutors. ${ }^{56}$ Even more dramatically, the title of Alemannos and Chamons article, "To Save the Rule of Law You Must Apparently

52 Nguyen, T. The EU's new rule of law mechanism How it works and why the 'deal' did not weaken it. Available: https://www.delorscentre.eu/en/publications/detail/publication/the-eus-new-rule-of-lawmechanism [last viewed 01.10.2021].

53 Regarding this aspect, see most recently, CJEU, C-896/19, Repubblika v Il-Prim Ministru.

54 See Hillion, C. Compromising (On) the General Conditionality Mechanism ...

55 Séville, A. Der Sound der Macht, Eine Kritik der dissonanten Herrschaft. Verlag C. H. Beck, 2018, S. $49 \mathrm{ff}$.

56 CJEU, C-508/18, C-82/19. 
Break It" ${ }^{27}$ illustrates that, ironically, in the process for enacting the conditionality mechanism at various instances, EU institutions seemed to fail respecting the EU law. Accordingly, this shows that the concerned legal acts need to be carefully reviewed by the CJEU, yet also by the public and scholars. Notwithstanding these aspects, it should be underlined that critics devoted to the deterioration of the rule of law concentrate on Poland and Hungary. ${ }^{58}$ In this context, one may take positive notice that the EU efforts to countering these authoritarian tendencies are sided by the ECHR, which, in a case concerning irregularities in the personal composition of the Polish Constitutional Tribunal (Xero Flor $w$ Polsce sp. z o.o. v. Poland) found a violation of "the right to a tribunal established by law". ${ }^{59}$

Finally, the analysis has shown that one of the mechanisms' main elements seems to be the fight against the (systemic) misuse of funds, fraud and corruption in Member States. The implementation in practice is problematic given that the EU depends on the institutions of the Member States. Here it is improbable that the beneficiaries of fraudulent activities will engage in procedures to their very detriment and the system thus depends on the independence of national authorities and a functioning sanctioning mechanism, should authorities be too lenient. However, clear and transparent guidelines decrease the (potential) leniency of national institutions when reviewing the administration and use of EU funds. Ultimately, the CJEU has been an important player in this process, when interpreting the legal provisions in this complex legal field. And, again somewhat ironically, also in this very field of funds, ${ }^{60}$ the CJEU has been reminded by Member States, political actors and legal scholars to enhance predictability and transparency in its adjudication and the interpretation of EU law. ${ }^{61}$ Though in a different field, it however, is not a sign of praise for the rule of law in the CJEUs judicial practice, if the German Bundesverfassungsgericht finds that [..] the judgment is simply not comprehensible so that, to this extent, the judgment was rendered ultra vires [...".62

In sum, this new mechanism is a novel and additional tool that promises to contribute to fostering the rule of law in Member States and the institutions. One should, however, be cautions not to overestimate the impact of this mechanism. The rule of law mechanism does not address the substantive (political) standards or specific values but rather sets the frame for the conditions of law - without them, a supranational organization cannot work. While the regulation does not conduct

57 Alemanno, A., Chamon, M. To Save the Rule ...

58 See particularly Koncewicz, T. T. How the EU is Becoming a Rule-of-Law-Less Union of States: From POLEXIT to E(U)EXIT? VerfBlog. 28.04.2021. Available: https://verfassungsblog.de/how-the-eu-isbecoming-a-rule-of-law-less-union-of-states/ [last viewed 01.10.2021].

59 Leloup, M. The ECtHR Steps into the Ring: The Xero Flor ruling as the ECtHR's first step in fighting rule of law backsliding. VerfBlog. 10.05.2021. Available: https://verfassungsblog.de/the-ecthr-stepsinto-the-ring/ [last viewed 01.10.2021]. DOI: 10.17176/20210510-181420-0; Szwed, M. What Should and What Will Happen After Xero Flor: The judgement of the ECtHR on the composition of the Polish Constitutional Tribunal. VerfBlog. 09.05.2021. Available: https://verfassungsblog.de/whatshould-and-what-will-happen-after-xero-flor/ [last viewed 01.10.2021]. DOI: 10.17176/20210509210914-0.

60 See CJEU, C-743/18 (LSEZ SIA/Latvijas Investīciju un attīstības aǵentūra) and comments by Schewe, C. EuGH: Investitionen, S. 119.

61 Klenk, L. Die Grenzen der Grundfreiheiten: Studien zum europäischen und deutschen Öffentlichen Recht 28.

Mohr Siebeck, 2019.

62 BVerfG, Urteil des Zweiten Senats vom 05. Mai 2020 -2 BvR 859/15, Rn. 116. Available: http://www. bverfg.de/e/rs20200505_2bvr085915.html; https://www.bundesverfassungsgericht.de/SharedDocs/ Entscheidungen/EN/2020/05/rs20200505_2bvr085915en.html. 
the matter regarding the allegations that the rule of law menaces national or cultural identity, it is predictable that similar aspects will arise in future disputes. The main problem will resemble a delicate evergreen of constitutional and international law: the distinction whether a dispute is to be considered political or judicial. However, beyond this mechanism in the EU these issues are frequently dealt with by other legal principles or secondary law and thus may become relevant to disputes and be adjudicated.

\section{Sources}

\section{Bibliography}

1. Alemanno, A., Chamon, M. To Save the Rule of Law you Must Apparently Break It. VerfBlog. 11.12.2020. Available: https://verfassungsblog.de/to-save-the-rule-of-law-you-must-apparentlybreak-it/ [last viewed 01.10.2021]. DOI: 10.17176/20201212-060201-0.

2. Bahners, P. Bärbel Bohley: Gerechtigkeit und Rechtsstaat. Frankfurter Allgemeine Zeitung, 14.10.2020. Available: https://www.faz.net/aktuell/feuilleton/debatten/baerbel-bohleys-zitatvon-gerechtigkeit-und-rechtsstaat-16996571.html [last viewed 01.10.2021].

3. Bogdandy, A. von. Tyrannei der Werte? Herausforderungen und Grundlagen einer europäischen Dogmatik systemischer Defizite. Zeitschrift für ausländisches öffentliches Recht und Völkerrecht, Bd. 79, H. 3, 2019, S. 503-551.

4. Braun, J. Einführung in die Rechtswissenschaft, Mohr Siebeck, 4. Aufl, Tübingen, 2011.

5. Dimitrovs, A., Droste, H. Conditionality Mechanism: What's In It? VerfBlog. 30.12.2020. Available: https://verfassungsblog.de/conditionality-mechanism-whats-in-it/ [last viewed 01.10.2021]. DOI: 10.17176/20201230-201659-0.

6. Grzeszick, B. Article 20. Bundesstaatliche Verfassung; Widerstandsrecht. In: Maunz, T., Dürig, G. Grundgesetz-Kommentar. 2020.

7. Györy, C. Ein Freund, ein guter Freund. VerfBlog. 22.12.2020. Available: https://verfassungsblog. de/ein-freund-ein-guter-freund/ [last viewed 01.10.2021]. DOI: 10.17176/20201222-172713-0.

8. Hilf, M., Schorkopf, F. Article 2 EUV. In: Grabitz, E., Hilf, M., Nettesheim, M. (Hrsg.). Das Recht der Europäischen Union, 69 Aufl. München, 2020.

9. Hillion, C. Compromising (On) the General Conditionality Mechanism and the Rule of Law (April 6, 2021). Common Market Law Review, No. 58, 2021, pp. 267-284. Available: https:// papers.ssrn.com/sol3/papers.cfm?abstract_id $=3820897$ [last viewed 01.10.2021].

10. Klenk, L. Die Grenzen der Grundfreiheiten: Studien zum europäischen und deutschen Öffentlichen Recht 28. Mohr Siebeck, 2019.

11. Koncewicz, T. T. How the EU is Becoming a Rule-of-Law-less Union of States: From POLEXIT to E(U)EXIT? VerfBlog. 28.04.2021. Available: https://verfassungsblog.de/how-the-eu-isbecoming-a-rule-of-law-less-union-of-states/ [last viewed 01.10.2021].

12. Leawoods, H., Radbruch, G. An Extraordinary Legal Philosopher. WASH. U. J. L. \& POL'Y. Vol. 2. Re-Engineering Patent Law: The Challenge of New Technologies, January 2000, p. 500. Available: https://openscholarship.wustl.edu/cgi/viewcontent.cgi?article=1516\&context=law_journal_ law_policy [last viewed 01.10.2021].

13. Leloup, $M$. The ECtHR Steps into the Ring: The Xero Flor ruling as the ECtHR's first step in fighting rule of law backsliding. VerfBlog. 10.05.2021. Available: https://verfassungsblog.de/ the-ecthr-steps-into-the-ring/ [last viewed 01.10.2021]. DOI: 10.17176/20210510-181420-0

14. Mader, O. Rechtsstaatlichkeit und Haushalt: Der Stand des Werteschutzes in der EU nach dem Streit über die Rechtsstaatsverordnung. Europäische Zeitschrift für Wirtschaftsrecht, Bd. 32, H. 4, 2021, S. 133-142.

15. Nguyen, T. The EU's new rule of law mechanism How it works and why the 'deal' did not weaken it. Available: https://www.delorscentre.eu/en/publications/detail/publication/the-eus-new-ruleof-law-mechanism [last viewed 01.10.2021].

16. Radbruch, G. Gesetzliches Unrecht und übergesetzliches Recht. Süddeutsche Juristenzeitung, Nr. 1, 1946, S. 105-108.

17. Scheppele, K. L., Pech, L., Kelemen, R. D. Never Missing an Opportunity to Miss an Opportunity: The Council Legal Service Opinion on the Commission's EU budget-related rule of law mechanism. VerfBlog. 12.11.2018. Available: https://verfassungsblog.de/never-missing-an-opportunity-tomiss-an-opportunity-the-council-legal-service-opinion-on-the-commissions-eu-budget-relatedrule-of-law-mechanism/ [last viewed 01.10.2021]. DOI: 10.17176/20181115-215538-0. 
18. Schewe, C. EuGH: Investitionen: Verstoß gegen eine Unionsbestimmung als Folge einer Handlung eines Wirtschaftsteilnehmers. Europäische Zeitschrift für Wirtschaftsrecht, Bd. 32, H. 3, 2021, S. 119-123.

19. Schmitt, C. Was bedeutet der Streit um den „Rechtsstaat“? Zeitschrift für die gesamte Staatswissenschaft, Bd. 95, H. 2, 1935, S. 189-201.

20. Schorkopf, F. Article 7 EUV. In: Grabitz, E., Hilf, M., Nettesheim, M. (Hrsg.). Das Recht der Europäischen Union. 69 Aufl. München, 2020, S. $70 \mathrm{ff}$.

21. Schorkopf, F. Wertesicherung in der Europäischen Union. Prävention, Quarantäne und Aufsicht als Bausteine eines Rechts der Verfassungskrise? Europarecht, Nr. 2, 2016, S. 147-163.

22. Séville, A. Der Sound der Macht, Eine Kritik der dissonanten Herrschaft. Verlag C. H. Beck, 2018.

23. Szwed, M. What Should and What Will Happen After Xero Flor: The judgement of the ECtHR on the composition of the Polish Constitutional Tribunal. VerfBlog. 09.05.2021. Available: https:// verfassungsblog.de/what-should-and-what-will-happen-after-xero-flor/ [last viewed 01.10.2021]. DOI: $10.17176 / 20210509-210914-0$.

24. Trentmann, C. Die Grundlagen des Rechtsstaatsbegriffs - Zugleich eine Einführung in die Rechtslehre Immanuel Kants und Robert von Mohls. Juristische Schulung, Nr. 10, 2017, S. 979-983.

25. Voßkuhle, A., Kaufhold, A.-K. Grundwissen - Öffentliches Recht: Das Rechtsstaatsprinzip. Juristische Schulung, Bd. 50, H. 2, 2010, S. 116-119.

\section{Court Decisions, Legal Acts and Conclusions}

1. European Council conclusions, EUCO 22/20 CO EUR 17 CONCL 8, 11 December 2020. Available: [last viewed 01.10.2021]

2. Regulation (EU, Euratom) 2020/2092 of the European Parliament and of the Council of 16 December 2020 on a general regime of conditionality for the protection of the Union budget. OJ, L 433I, 22.12.2020, pp. 1-10. Available: https:/eur-lex.europa.eu/legal-content/en/ TXT/?uri=CELEX\%3A32020R2092 [last viewed 01.10.2021].

\section{Case Law}

1. Judgement of ECJ of 23 April 1986 in case No. 294/83, p. 23. Available: https://eur-lex.europa.eu/ legal-content/EN/TXT/?uri=CELEX:61983CJ0294 [last viewed 14.05.2021].

\section{Other Sources}

1. Venice Commission of the Council of Europe, Rule of Law Checklist. Available: https://www. venice.coe.int/webforms/documents/default.aspx?pdffile=CDL-AD(2016)007-e [last viewed 14.05.2021].

2. European Commission, Rule of law mechanism. Available: https://ec.europa.eu/info/policies/ justice-and-fundamental-rights/upholding-rule-law/rule-law/rule-law-mechanism_en [last viewed 01.10.2021].

3. Gutscher, T. Polen und Ungarn klagen gegen EU-Rechtsstaatsmechanismus. 11.03.2021. Available: https://www.faz.net/aktuell/politik/ausland/polen-und-ungarn-klagen-gegen-eu-rechtsstaatsmec hanismus-17238896.html [last viewed 01.10.2021].

4. Löwenstein, S. Es geht um Erpressung. FAZ. 17.11.2020. Available: https://www.faz.net/aktuell/ politik/ausland/ungarns-justizministerin-varga-es-geht-um-erpressung-17056871.html [last viewed 01.10.2021]. 